\title{
The Effect of Protein Synthesis Inhibition on Petal Senescence in Cut Bulb Flowers
}

\author{
Rodney B. Jones ${ }^{1}$, Margrethe Serek ${ }^{2}$, Chen-Lan Kuo, and Michael S. Reid \\ Department of Environmental Horticulture, University of California, Davis, CA 95616 \\ Additional index words. Gladiolus, Iris, Narcissus, Tulipa, wilting inhibition
}

\begin{abstract}
Petal opening and senescence of cut Gladiolus, Iris, and Narcissus flowers was significantly inhibited by continuous treatment with $1 \mathrm{mMCHI}$. Vase life was doubled in individual flowers treated when half-open, and a similar effect was detected after pulsing cut gladiolus spikes with $1 \mathrm{~mm}$ CHI for 24 hours. Petal wilting was markedly inhibited in flowers treated with CHI and was confined to the outer 2 to $3 \mathrm{~mm}$ of petal margins as opposed to the entire petal in untreated flowers. These effects were not seen, however, in CHI-treated cut tulip flowers, where vase life was significantly reduced. CHI markedly inhibited protein synthesis in Gladiolus 'New Rose' florets (a decrease of $>60 \%$ ). Treatment with a potent biocide, DICA, did not increase vase life; therefore, $\mathrm{CHI}$ was not prolonging flower longevity by preventing microbial growth in the vase solution. The results indicate that de novo protein synthesis is required for bulb flower development and opening and petal wilting and senescence. Chemical names used: cycloheximide (CHI), sodium dichloroisocyanuric acid (DICA).
\end{abstract}

Although bulb flowers make up a substantial proportion of the cut-flower trade, there are comparatively few studies on the senescence of these flowers compared to more ethylene-sensitive flowers, such as carnations (Reid and Wu, 1992). Petal senescence in the bulb flowers Gladiolus, Iris, Narcissus, and Tulipa, for example, is generally considered to be ethylene-insensitive, as application of exogenous ethylene has little effect (Woltering and van Doorn, 1988). Similarly, postharvest pulsing with silver thiosulphate did not significantly improve vase life in Gladiolus spikes (Farhoomand, 1978; Mor et al., 1981). In a more detailed study investigating several cultivars, Serek et al. (1994) reported that some Gladiolus cultivars exhibit a climacteric rise in respiration and ethylene production, but that applying exogenous ethylene did not affect vase life, thus confirming that senescence in Gladiolus was ethylene-insensitive.

Studies of Iris and Gladiolus petal senescence indicated a gradual progression in senescence, without the accelerated wilting associated with climacteric ethylene production (Bravdo et al., 1974; Tirosh et al., 1983). Pulsing or continuously applying sucrose enhanced longevity in Gladiolus flowers and had a slightly beneficial effect on Iris (Bravdo et al., 1974; Tirosh et al., 1983). Other than studies on daylily (Lay-Yee et al., 1992; Lukaszewski and Reid, 1989), there are few known studies investigating the physiological or genetic mechanisms involved in petal wilting and senescence of ethylene-insensitive flowers.

In this paper we report the effects of $\mathrm{CHI}$ on flower opening and petal wilting in several cultivars of Gladiolus, Iris, Narcissus, and Tulipa.

Received for publication 27 Jan. 1994. Accepted for publication 19 May 1994. We thank Mercedes Fernandez Sanchez and Janyce Truett for their skilled technical assistance and Gladaway Nursery, Fremont, Calif., for supplying cut gladiolus. Funding for this study was provided by the Australian Dept. of Industry, Technology and Commerce Bilateral Science Exchange Program; Danish Agricultural and Veterinary Council (grant 13-4549); Foundation of Hofmansgave; Foundation of Ib Henriksen; and the Carlsberg Foundation. The cost of publishing this paper was defrayed in part by the payment of page charges. Under postal regulations, this paper therefore must be hereby marked advertisement solely to indicate this fact. ${ }^{1}$ Permanent address: Institute for Horticultural Development, Knoxfield, Private Bag 15, South Eastern Mail Centre, Victoria 3176, Australia. To whom reprint requests should be addressed.

2Permanent address: The Royal Veterinary and Agricultural University, Section for Horticulture, Rolighedsvej 23, DK-1958 Frederiksberg C., Denmark.

\section{Materials and Methods}

Plant materials. Cut Gladiolus, Iris, Narcissus, and Tulipa were harvested at normal commercial maturity, shipped to the laboratory within $24 \mathrm{~h}$ of harvest, and placed in deionized (DI) water under controlled conditions [20C, $50 \%$ to $60 \%$ relative humidity (RH), $15 \mu \mathrm{mol} \cdot \mathrm{m}^{-2} \cdot \mathrm{s}^{-1}$ for $12 \mathrm{~h} /$ day]. Where indicated, individual Gladiolus florets were excised from spikes at four stages of development: bud, first color, half-open, and fully open (Serek et al., 1994). Iris, Narcissus, and Tulipa flowers were used at the first sign of color (Iris and Tulipa) and one bell open per spike (Narcissus). In all studies, vase life was considered terminated at the first sign of petal wilting of the first open flower.

CHI treatments. Optimal CHI concentrations and effects on floret opening were studied using individual florets of Gladiolus 'Saint Patrick'. Fully open florets were excised from the spike; placed in $15-\mathrm{ml}$ vials containing DI water or $0.1,0.5,1.0$, or $2.0 \mathrm{~mm}$ CHI (Sigma Chemical Co., St. Louis); and placed under controlled conditions (20C, $50 \%$ to $60 \% \mathrm{RH}, 15 \mu \mathrm{mol} \cdot \mathrm{m}^{-2} \cdot \mathrm{s}^{-1}$ for $12 \mathrm{~h} / \mathrm{day}$ ). Flower diameter was measured daily using hand-held calipers, and vase life was assessed according to the criteria described above. The effect of CHI on floret opening was further investigated using Gladiolus 'Saint Patrick' florets excised at the four stages of development described above. The excised florets were placed in 1 MM CHI under controlled conditions. Flower diameter was measured daily using hand-held calipers and vase life was assessed.

To determine the effect of CHI on Gladiolus inflorescences, freshly harvested 'Saint Patrick' spikes were placed in DI water or $1 \mathrm{~mm} \mathrm{CHI} \mathrm{for} 24 \mathrm{~h}$ at $20 \mathrm{C}$ and then placed in DI water. The number of half-open, fully open, and senescent flowers was counted daily until all open flowers had senesced.

The effect of $1 \mathrm{~mm}$ CHI on a variety of nonclimacteric flowers was investigated using Gladiolus 'Saint Patrick', 'New Rose', 'Rose Supreme' 'Friendship', 'T512', and 'White Friendship' (individual florets); Iris 'Prof. Blaauw', 'Ideal', and 'Yellow Queen', Tulipa 'Apeldoorn', 'Don Quichotte', and 'White Dream'; and Narcissus 'Cheerfulness'. Each cultivar $(\mathrm{n}=10)$ was placed in DICA at $30 \mathrm{mg} \cdot$ liter $^{-1}$ or $1 \mathrm{~mm}$ CHI under standard conditions to assess vase life, with each trial repeated twice. DICA is a particularly effective germicide (Jones and Hill, 1993) and was used as a control to evaluate the possibility that the effects of $\mathrm{CHI}$ were due to germicidal activity. 
Protein turnover. Fully open Gladiolus 'New Rose' florets were pulsed for $24 \mathrm{~h}$ with 0.5 or $1.0 \mathrm{~mm} \mathrm{CHI}$ at $20 \mathrm{C}$ under 15 $\mu \mathrm{mol} \cdot \mathrm{m}^{-2} \cdot \mathrm{s}^{-1}$ constant light. After pulsing, two flowers from each treatment were excised, and $50 \mu$ l of DI water containing $5 \mu \mathrm{Ci}^{35} \mathrm{~S}$ methionine (in vivo cell labeling grade, Amersham, Arlington Heights, Ill.) was placed on each flower base. After $5 \mathrm{~h}$, petal tissues were excised and ground in liquid $\mathrm{N}_{2}$. The resulting powder was placed on Whatman no. $2 \mathrm{G}$ filter paper, and water-soluble proteins were eluted with several changes of water (total eluate 5 $\mathrm{ml}$ ). Bovine serum albumin (Sigma Chemical Co.) was added to the filtrate to a final concentration of $0.2 \%$. The filtrate was brought to $10 \%$ trichloroacetic acid to precipitate proteins, and the solution was held overnight at $2 \mathrm{C}$. Precipitated labeled proteins were filtered on a $0.45-\mu \mathrm{m}$ filter (Millipore Corp., Bedford, Mass.), and the radioactivity of the filter was measured on a scintillation counter (1215 Rackbeta; LKB Wallac, Finland).

Statistics. Statistical procedures were performed using the $\mathrm{PC}-$ SAS software package (SAS Institute, 1985). The variance of the experimental data was tested and orthogonal comparisons or $t$ tests were used to examine differences between means.

\section{Results}

CHI treatments. The vase life of half-open Gladiolus 'Saint Patrick' florets was significantly increased by continuous treatment with $\mathrm{CHI}$ concentrations of 0.1 to $1 \mathrm{~mm}$ (Fig. 1). The optimal CHI concentrations of 0.5 and $1 \mathrm{~mm}$ resulted in an increase in vase life of $100 \%$ (3 days; Table 1). Higher CHI concentrations ( $2 \mathrm{~mm}$ ) damaged petal tissue after 3 days, causing brown lesions and decreasing vase life (Fig. 1). Based on these results, we used $1 \mathrm{~mm} \mathrm{CHI} \mathrm{in} \mathrm{subsequent}$ trials.

Applying CHI resulted in a profound effect on floret opening, expressed as floret diameter in Gladiolus 'Saint Patrick' (Fig. 2 ad). Immature flowers developed and expanded in DI water, but CHI inhibited petal expansion (Fig. 2 a-c). Although develop-

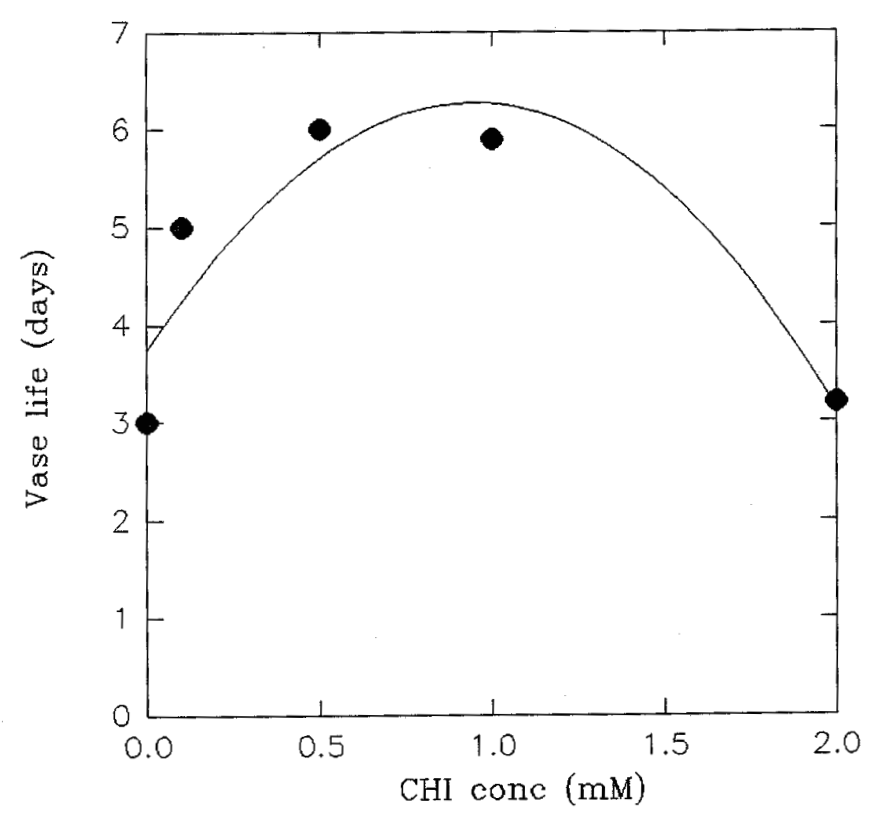

Fig. 1. Fitted curve representing the effect of varying CHI concentration on vase life of individual Gladiolus 'Saint Patrick' florets. Florets (half-open stage) were placed in $\mathrm{CHI}$ concentrations of 0 to $2 \mathrm{~mm}$ and vase life was assessed under controlled conditions at $20 \mathrm{C}$. $\mathrm{Y}=3.7+5.7(\mathrm{x})-2.5\left(\mathrm{x}^{2}\right)$, where $\mathrm{Y}=$ vase life and $\mathrm{x}=\mathrm{CHI}$ concentration. Adjusted $R^{2}=80.4 ; \mathrm{SE}=0.75(\mathrm{x}), 0.36\left(\mathrm{x}^{2}\right)$.
Table 1. Vase life (days) of Gladiolus 'Saint Patrick' florets placed in deionized (DI) water or CHI (1 mM). Florets were treated when open (petals fully expanded, postanthesis); half-open (petals partially expanded, preanthesis); bud (tight bud); or first color (first sign of petals through the sheath).

\begin{tabular}{lcccc}
\hline \hline & \multicolumn{4}{c}{ Vase life (days) } \\
\cline { 2 - 5 } & Open & Half-open & Bud & First color \\
\hline DI water & $3.7 \mathrm{a}^{\mathrm{z}}$ & $5.7 \mathrm{a}$ & $7.0 \mathrm{a}$ & $7.0 \mathrm{a}$ \\
CHI & $6.0 \mathrm{~b}$ & $8.3 \mathrm{~b}$ & $8.3 \mathrm{~b}$ & $8.0 \mathrm{~b}$
\end{tabular}

${ }^{\mathrm{z}}$ Mean separation within columns at $P=0.05$ by $t$ test for the hypothesis $\mathrm{H}_{\mathrm{o}}: \operatorname{LSM}(\mathrm{i})=\operatorname{LSM}(\mathrm{j})$.

Table 2. Vase life (days) of gladiolus, iris, tulip, and narcissus flowers placed in deionized (DI) water or CHI (1 mM). Flowers were treated when half-open (petals partially expanded, preanthesis).

\begin{tabular}{|c|c|c|c|}
\hline \multirow[b]{2}{*}{ Species } & \multicolumn{2}{|c|}{ Treatment } & \multirow{2}{*}{$\begin{array}{c}\text { Source of } \\
\text { variation } \\
\text { (DI vs. CHI) }\end{array}$} \\
\hline & $\begin{array}{c}\text { DICA } \\
\left(20 \mathrm{mg} \cdot \text { liter }^{-1}\right)\end{array}$ & $\begin{array}{c}\text { CHI } \\
(1 \mathrm{mM})\end{array}$ & \\
\hline \multicolumn{4}{|l|}{ Gladiolus } \\
\hline Saint Patrick & 3.6 & 6.6 & $*$ \\
\hline New Rose & 3.2 & 4.2 & $*$ \\
\hline Rose Supreme & 4.2 & 7.0 & $*$ \\
\hline Friendship & 4.0 & 7.0 & $* *$ \\
\hline T512 & 3.2 & 9.0 & $* * *$ \\
\hline White Friendship & 4.4 & 8.8 & $* *$ \\
\hline \multicolumn{4}{|l|}{ Iris } \\
\hline Prof. Blaauw & 3.3 & 5.0 & $*$ \\
\hline Ideal & 3.3 & 5.3 & $* *$ \\
\hline Yellow Queen & 3.3 & 6.0 & $*$ \\
\hline \multicolumn{4}{|l|}{ Tulipa } \\
\hline Apeldoorn & 5.6 & 4.8 & $*$ \\
\hline Don Quichotte & 4.2 & 3.0 & $* *$ \\
\hline White Dream & 4.8 & 3.1 & $* *$ \\
\hline \multicolumn{4}{|l|}{ Narcissus } \\
\hline Cheerfulness & 2.6 & 5.5 & $* *$ \\
\hline
\end{tabular}

ment and expansion continued in florets at the half-open, bud, and first-color stages during the first day after $\mathrm{CHI}$ application, they ceased thereafter. The diameter of fully open florets was maintained by $1 \mathrm{~mm} \mathrm{CHI}$, while the diameter of florets placed in DI water declined significantly as the petals senesced (Fig. 2d).

The effect of CHI on vase life of a range of nonclimacteric bulb flowers is presented in Table 2. DICA was added to DI water to compare the effects of CHI to those of an effective germicide of species for which DICA does not improve vase life (Jones and Hill, 1993). CHI significantly improved vase life over DICA in all six Gladiolus cultivars tested: 'Saint Patrick', 'New Rose', 'Rose Supreme', 'Friendship', 'T512', and 'White Friendship'.

Applying $1 \mathrm{~mm} \mathrm{CHI} \mathrm{also} \mathrm{significantly} \mathrm{improved} \mathrm{vase} \mathrm{life} \mathrm{in} \mathrm{Iris}$ 'Prof. Blaauw', 'Ideal', and 'Yellow Queen' and Narcissus 'Cheerfulness'. Vase life decreased, however, in Tulipa 'Apeldoorn', 'Don Quichotte', and 'White Dream' (Table 2). CHI-treated Tulipa flowers failed to open, prematurely lost petal color, and stems failed to elongate or respond to light (data not shown), resulting in a shorter vase life.

To test the effect of CHI on whole spikes, 'Saint Patrick' inflorescences were pulsed with $1 \mathrm{~mm} \mathrm{CHI} \mathrm{for} 24 \mathrm{~h}$. Vase life was significantly improved in florets already open, but opening of 

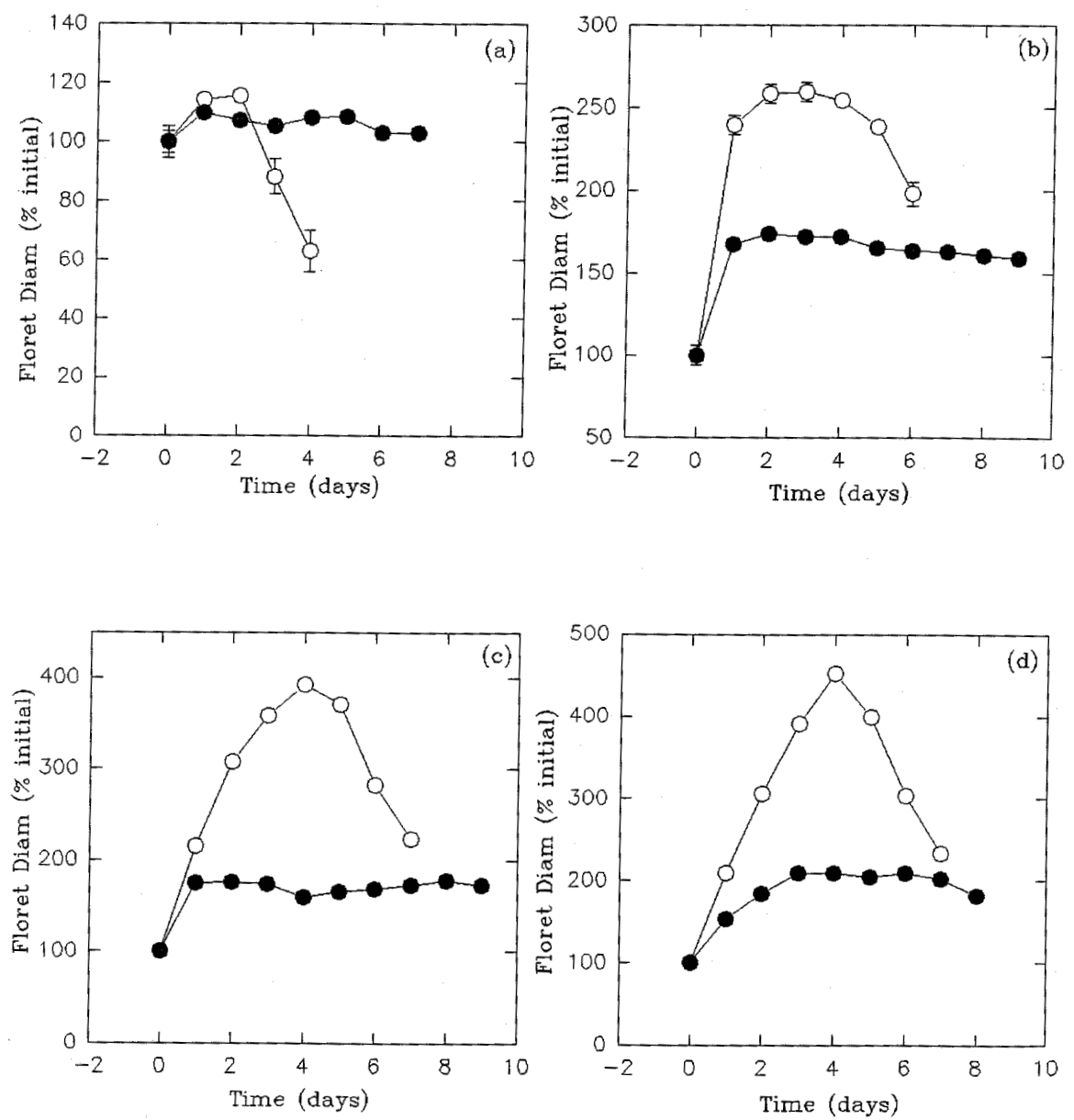

Fig. 2. The effect of $1 \mathrm{~mm} \mathrm{CHI} \mathrm{on} \mathrm{floret} \mathrm{opening} \mathrm{(expressed} \mathrm{as} \mathrm{floret} \mathrm{diameter)} \mathrm{in} \mathrm{Gladiolus} \mathrm{'Saint} \mathrm{Patrick'} \mathrm{florets} \mathrm{at} \mathrm{four} \mathrm{stages} \mathrm{of} \mathrm{development:} \mathrm{(a)} \mathrm{first} \mathrm{color,} \mathrm{(b)} \mathrm{bud,}$ (c) half- open, and (d) fully open. Individual florets were placed in DICA $(O)$ or $1 \mathrm{~mm} \mathrm{CHI}(\bullet)$ at 20C. Bars represent SE.

Source of variation:

Treatment $\times$ time

$\begin{array}{lllll}\text { Deionized water vs. CHI } \times \text { linear } & * * * & \text { Ns } & * * & \text { NS } \\ \text { Deionized water vs. CHI } \times \text { quadratic } & * * & * * * & * * * & * * *\end{array}$

a $\quad$ b $\quad c \quad c \quad d$

ss,**,****Nonsignificant or significant at $P=0.01$ or 0.001 , respectively.

immature buds was completely inhibited (Fig. 3). While buds continued to develop and open on spikes pulsed in DI water, very little bud development was observed in spikes treated with CHI. Floret senescence commenced after 3 days in control spikes, but was delayed until 6 days in CHI-treated spikes (Fig. 3), reflecting the improvement in vase life observed in individual florets (Table 1).

Protein synthesis. Incorporating ${ }^{14} \mathrm{C}$-Methionine into soluble protein in Gladiolus 'New Rose' petal tissue was severely inhibited in flowers that had been treated with 0.5 and $1 \mathrm{~mm} \mathrm{CHI} \mathrm{(Table}$ 3 ). Levels of labeled protein decreased by $\approx 44 \%$ and $64 \%$ with 0.5 and $1.0 \mathrm{~mm} \mathrm{CHI}$, respectively.

\section{Discussion}

Despite many studies on the mechanisms involved in flower senescence, our knowledge of the genetic and biochemical events that lead to vase life termination in cut flowers is still limited (Stead, 1992). Most studies have concentrated on the accelerated senescence caused by ethylene in flowers such as carnations, in which ethylene is thought to act by altering gene expression (Woodson and Lawton, 1988). Little is known of the sequence of events controlling petal senescence in ethylene-insensitive flowers, particularly the commercially important bulb flowers such as Tulipa, Iris, Gladiolus, and Narcissus.
$\mathrm{CHI}$ is a general inhibitor of de novo protein synthesis in plant tissue (Ap Rees and Bryant, 1971), and acts as a potent inhibitor of cut-flower senescence. Applying CHI resulted in the inhibition of membrane deterioration in Ipomea corolla tissue (Suttle and Kende, 1980) and daylily (Bieleski and Reid, 1991), possibly because CHI blocked the synthesis of enzymes responsible for the loss of membrane integrity (Halaba and Rudnicki, 1986). In the study reported here, incubating Gladiolus, Iris, and Narcissus cut flowers in $1 \mathrm{~mm}$ CHI substantially improved vase life (Table 2) due to an almost complete inhibition of petal expansion (Fig. $2 \mathrm{a}-\mathrm{c}$ ) and wilting.

CHI did not affect solution uptake by cut flowers and does not seem to have germicidal activity (data not shown), results indicating that the improved flower longevity caused by CHI was not due to increased water uptake caused by microorganism control, rather an inhibition of de novo protein synthesis. In Gladiolus, for example, petal expansion depends on an adequate carbohydrate supply, as applying carbohydrates to cut flowers promoted floret opening (Bravdo et al., 1974). CHI may prevent petal expansion by inhibiting the synthesis of hydrolytic enzymes that are responsible for releasing osmotically active solutes. In this case, CHI may block the synthesis of enzymes involved in starch hydrolysis, as is seen in carnations (Ho and Nichols, 1977), or fructan hydrolysis, as seen in daylily (Bieleski, 1993). This action inhibits the decline 


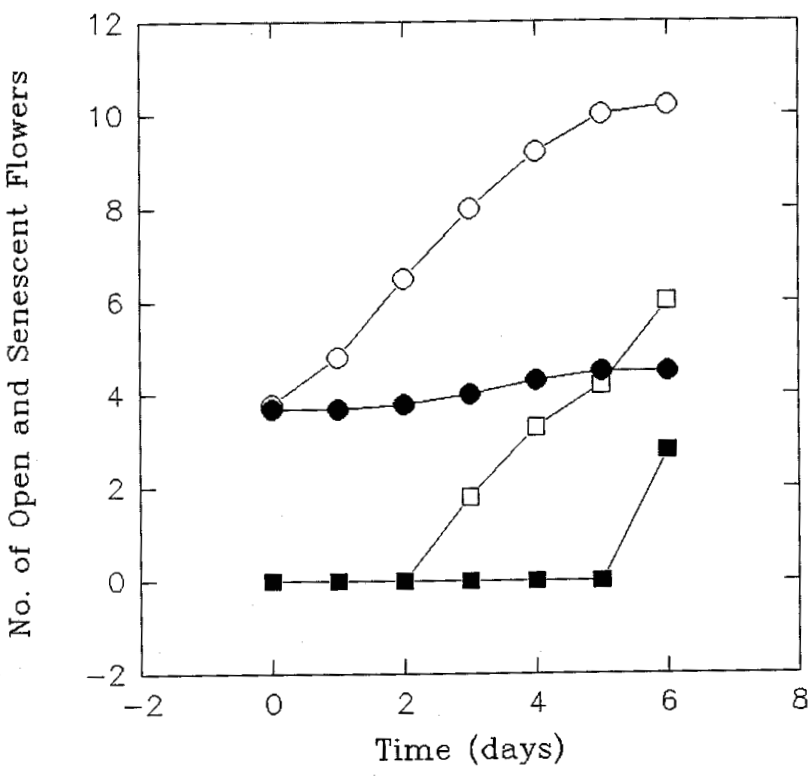

Fig. 3. Effect of a 24-h pulse of deionized (DI) water (open symbols) or $1 \mathrm{~mm} \mathrm{CHI}$ (closed symbols) on floret opening and closure in complete Gladiolus 'Saint Patrick' spikes. Spikes were pulsed in $1 \mathrm{~mm} \mathrm{CHI} \mathrm{for} 24 \mathrm{~h}$ at $20 \mathrm{C}$.

$\mathrm{O}=$ number of open florets after deionized (DI) water pulse

$\square=$ number of closed florets after DI water pulse

= number of open florets after $\mathrm{CHI}$ pulse

= number of closed florets after $\mathrm{CHI}$ pulse

Source of variation:

$\begin{array}{lll}\text { Treatment } \times \text { time } & \text { Open } & \text { Dead } \\ \text { DI vs. CHI } \times \text { linear } & * * * & * * *\end{array}$

DI vs. $\mathrm{CHI} \times$ quadratic

*** $\quad$ ****

Ns,**,*** Nonsignificant or significant at $P=0.01$ or 0.001 , respectively.

in petal osmotic potential and resultant influx of water to expand petal tissue. The CHI-induced inhibition of petal expansion (Fig. 2) clearly shows the requirement for de novo protein synthesis in this aspect of petal development.

Furthermore, CHI-treated bulb flowers failed to develop an almost complete loss of turgor seen in untreated flowers, resulting in a dramatic extension of vase life (Table 2). Wilting in CHItreated flowers was only visible in the outer 1 to $2 \mathrm{~mm}$ of the petals (data not shown), and this wilting may have occurred because CHI did not reach these areas. CHI also inhibited wilting in cut 'White Sim' carnations (Drory et al., 1989; Wulster et al., 1982) and daylily (Bieleski and Reid, 1991; Lay-Yee et al., 1992).

In ethylene-sensitive flowers such as morning glory and carnation, the onset of senescence is associated with the up-regulation of specific mRNAs (Lawton et al., 1989) and de novo synthesis of a range of enzymes, including glucosidases, $\beta$-glucosidase, $\beta$ galactosidase, laminarinase, and cellobiase (Wiemken-Gehrig et al., 1974). The increase in $\beta$-glucosidase activity at the onset of wilting in Ipomea was inhibited by CHI, a result that was interpreted as evidence that the increased activity of this enzyme was due to de novo synthesis (Matile and Winkenbach, 1971). Further evidence for the inhibition of de novo protein synthesis by $\mathrm{CHI}$ includes the inhibited incorporation of labeled methionine into soluble proteins in Gladiolus petal tissue by $>60 \%$ by $1 \mathrm{~mm} \mathrm{CHI}$ (Table 3). Inhibited wilting and senescence by $\mathrm{CHI}$ in a range of nonclimacteric flowers (Table 2) indicates that senescence in these flowers also depends on de novo protein regulation, as in the more intensely studied carnation and morning glory flowers.

Tulipa 'Apeldoorn', 'Don Qichotte', and 'White Dream' flowers treated with $1 \mathrm{~mm} \mathrm{CHI}$ failed to open, lost their gravitropic
Table 3. Effect of 0.5 and $1.0 \mathrm{mM}$ cycloheximide (CHI) on radioactivelabeled protein in Gladiolus petal tissue. Labeled protein is expressed as a percent of the radioactivity of untreated (control) petal tissue.

\begin{tabular}{lc}
\hline \hline Treatment & $\begin{array}{r}\text { Radioactivity } \\
\text { (\% control) }\end{array}$ \\
\hline Deionized water & 100.0 \\
CHI $0.5 \mathrm{mM}$ & 56.4 \\
CHI $1.0 \mathrm{mM}$ & 36.3 \\
Source of variation & $* *$ \\
Deionized water vs. $0.5 \mathrm{mM} \mathrm{CHI}$ & $* *$ \\
Deionized water vs. $1.0 \mathrm{mM} \mathrm{CHI}$ & $*$ \\
0.5 mM CHI vs. $1.0 \mathrm{mM} \mathrm{CHI}$ & $* *$ \\
CHI, linear & $* *$ \\
CHI, quadratic & \\
\hline$* *$ Signicant $P$ & 0.050 0.01, respectively.
\end{tabular}

*,*** Significant at $P=0.05$ or 0.01 , respectively.

response, and prematurely lost color (data not shown). Similar results have been reported when Tulipa 'Apeldoorn' and 'Elmus' were treated with 2 to $4 \mathrm{~mm}$ CHI (Nichols, 1977). Unlike Gladiolus, Iris, and Narcissus, Tulipa treated with CHI wilted before control stems (placed in DICA), leading to reduced vase life (Table 2). It seems possible that the inhibition of protein synthesis in these flowers interferes so drastically with maintenance metabolism that the flowers perish early.

In conclusion, our results imply that petal wilting and senescence in certain bulb flowers (Gladiolus, Iris, and Narcissus) relies on de novo protein regulation. Unlike ethylene-sensitive flowers such as carnations, petal senescence is not accelerated by ethylene but is controlled by a more ordered sequential gene expression. $\mathrm{CHI}$ is the most effective chemical reported for improving vase life in these commercially important bulb flowers, but it cannot be recommended for commercial use due to the inhibition of floret expansion, and its unacceptable toxicity to humans. A more effective means of extending vase life in these flowers may be to manipulate the regulation of de novo synthesis of the enzymes responsible for the onset of petal senescence.

\section{Literature Cited}

Ap Rees, T. and J.A. Bryant. 1971. Effects of cycloheximide on protein synthesis and respiration in disks of carrot storage tissue. Phytochemistry 10:1183-1190.

Bieleski, R.L. 1993. Fructan hydrolysis drives petal expansion in the ephemeral daylily flower. Plant Physiol. 103:213-219.

Bieleski, R.L. and M.S. Reid. 1991. Physiological changes accompanying senescence in the ephemeral daylily flower. Plant Physiol. 98:10421049.

Bravdo, B., S. Mayak, and Y. Gravrieli. 1974. Sucrose and water uptake from concentrated sucrose solutions by gladiolus shoots and the effect of these treatments on floret life. Can. J. Bot. 52:1271-1281.

Drory, A., S. Mayak, and A. Borochov. 1989. Interaction of petal portions, hormones and protein biosynthesis in the responses of carnation petals to water stress. Acta Hort. 261:91-96.

Farhoomand, M.B. 1978. Prolonging vase life of cut carnation and gladiolus by chemicals. HortScience 13(3):26. (Abstr.)

Ho, L.C. and R. Nichols. 1977. Translocation of ${ }^{14} \mathrm{C}$-sucrose in relation to changes in carbohydrate content in rose corollas cut at different stages of development. Ann. Bot. 41:227-42.

Halaba, J. and R.M. Rudnicki. 1986. The role of enzymes during senescence of cut flowers. Acta Hort. 181:65-74.

Jones, R.B. and M. Hill. 1993. The effect of germicides on the longevity of cut flowers. J. Amer. Soc. Hort. Sci. 118:350-354.

Lawton, K.A., B. Huang, P.B. Goldsbrough, and W.R. Woodson. 1989. Molecular cloning and characterization of senescence-related genes 
from flower petals. Plant Physiol. 90:690-696.

Lay-Yee, M., A.D. Stead, and M.S. Reid. 1992. Flower senescence in daylily (Hemerocallis). Physiol. Plant. 86:308-314.

Lukaszewski, T.A. and M.S. Reid. 1989. Bulb-type flower senescence. Acta Hort. 261:59-62.

Matile, P. and F. Winkenbach. 1971. Function of lysosomes and lysosomal enzymes in the senescing corolla of the morning glory (Ipomea purpurea). J. Expt. Bot. 22:759-771.

Mor, Y., R.E. Hardenburg, A.M. Kofranek, and M.S. Reid. 1981. Effect of STS pretreatment on vase life of cut standard carnations, spray carnations and gladiolus, after a transcontinental truck shipment. HortScience 16:766-768.

Nichols, R. 1977. Cycloheximide and senescence of bulb flowers. The Glasshouse Crops and Res. Inst., Littlehampton Annu. Rpt. p. 60-61.

Reid, M.S. and M-J. Wu. 1992. Ethylene and flower senescence. Plant Growth Regulat. 11:37-43.

SAS Institute. 1985. SAS/STAT guide for personal computer. Version 6. SAS Inst., Cary, N.C.

Serek, M., R.B. Jones, and M.S. Reid. 1994. Role of ethylene in opening and senescence of gladiolus (Gladiolus sp.) flowers. J. Amer. Soc. Hort.
Sci. 119:1014-1019.

Stead, A.D. 1992. Pollination-induced flower senescence: A review. Plant Growth Regulat. 11:13-20.

Suttle, J.C. and H. Kende. 1980. Ethylene action and loss of membrane integrity during petal senescence in Tradescantia. Plant Physiol. 65:10671072.

Tirosh, T., S. Mayak, and A.H. Halevy. 1983. Inter-related effects of short-term treatment with nutritive solution and shipment conditions on the quality of iris flowers. Scientia Hort. 19:161-166.

Wiemken-Gehrig, V., A. Wiemken, and P. Matile. 1974. Mobilisation von Zellwandstoffen in der welkenden Blüte von Ipomea tricolor Cav. Planta 115:297-307.

Woltering, E.J. and W.G. van Doorn. 1988. Role of ethylene in senescence of petals-Morphological and taxonomic relationships. J. Expt. Bot. 39:1605-1606.

Woodson, W.R. and K.A. Lawton. 1988. Ethylene-induced gene expression in carnation petals. Plant Physiol. 87:498-503.

Wulster, G., J. Sacalis, and H. Janes. 1982. The effect of inhibitors of protein synthesis on ethylene-induced senescence in isolated carnation petals. J. Amer. Soc. Hort. Sci. 107:112-115. 